\title{
Evaluation of the correlation between SPAD readings and absolute chlorophyll content of maize under different nitrogen supply conditions
}

\author{
Attila Simkó - Szilvia Veres \\ University of Debrecen, Faculty of Agricultural and Food Sciences and Environmental Management, Institute of Plant Sciences, Department \\ of Agricultural Botany, Crop Physiology and Biotechnology, Debrecen, Hungary \\ simko.attila@agr.unideb.hu
}

SUMMARY

\begin{abstract}
Currently, one of the most important objectives of agriculture is to maintain the principles of the sustainability. The use of precision technologies in agriculture belongs to this topic. The use of precision technologies is increasingly widespread in the cultivation of various agricultural crops, including maize. Sensing is an important part of these techniques. In our experiment we compared two methods: measuring relative chlorophyll content and the method of determine the extractable chlorophylls. The experimental plant was maize (Zea mays L.) and the measurements were performed at an early development stage (V8) of three genotypes. Three levels of nitrogen (0; $80 ; 160$ $\mathrm{kg} \mathrm{ha}^{-1}$ ) were applied during the experiment. The relative chlorophyll content was measured by SPAD-502 (Minolta, Japan) and a handheld GreenSeeker (Trimble, USA) device. The extractable total chlorophyll content decreased in parallel with the increased nitrogen level. The obtained SPAD values were diversified furthermore the NDVI values have not been changed for the effect of different nitrogen fertilization. In the early stages of development of maize, these parameters need to be complemented with other measurements to provide reliable information about the crops nitrogen status.
\end{abstract}

Keywords: Chlorophyll, SPAD, NDVI, maize

\section{INTRODUCTION}

Currently, agriculture has to overcome with the global problems of our days like over population or global climate change. The optimization of agrotechnological elements reduces the negative effects of the global climate change in the crop production (Pepó, 2010). Precision technologies in agriculture can reduce the harm effects of weather factors. The use of this technologies is increasing widespread in the cultivation of various agricultural crops, including maize production. Sensor sensing is an important part of these techniques. The quantitative examination of the photosynthetic pigments can be useful in the plant stress research (Peñuelas and Filella, 1998). The optimal nitrogen nutrition is one of the most important factor in term of successful plant production. There is a correlation between the leaves' chlorophyll content and the plant's nutrient status (Moran et al., 2000). The optical non-destructive methods for measuring leaves relative chlorophyll content are fast, easy to use, and gives reliable information of relative leaf chlorophyll content (Richardson et al., 2002), and provide reliable information about crops nitrogen status at the vegetative development stages (Chapman and Baretto, 1997). The SPAD-502 and a handheld GreenSeeker device also applicable for determining relative chlorophyll contents. The SPAD-502 has visualized the relative chlorophyll content as SPAD (Soil Plant Analysis Development) value while the GreenSeeker shows the results as Normalized Difference Vegetation Index (NDVI). Lu et al. (2011) claimed the NDVI value supplemented with other measurements is reliable to the examination of drought stress, while Schlemmer et al. (2013) was used a remote sensing method with Sentinel-2 satellite for examine the effect of nitrogen deficiency. Verhulst et al. (2011) examined wheat and maize plants under different tillage and crop rotation systems with handheld NDVI sensor. They have observed a strong correlation between biomass accumulation and NDVI values. The SPAD-502 device is appropriate for the examination of crop status at the silking stage in maize (Simkó et al., 2018). Costa et al. (2001) also found a correlation between the applied nitrogen rates and the SPAD meter readings. Nitrogen deficiency can be indicated by the SPAD value with great security (Széles, 2007). Nagy (2010) found that the SPAD reading strongly correlated with the irrigation and the increasing of the SPAD value was observed as the result of the fertilization. The destructive determination of photosynthetic pigments is a widespread technique in the plant research. Jiang et al. (2017) found a significant relationship between SPAD-502 value and chlorophyll content in tomato leaves. Several factors can influence the total amount of photosynthetic pigment, such as salt stress (Purcărea and CachițăCosma, 2010), microelements (Garousi et al., 2015) and nitrogen fertilizer levels (Hafez and Abdelaal, 2015). Deficiencies of individual nutrients affected significantly the photochemical processes (Kalaji et al., 2014). Hammad et al. (2011) observed significant decreasing of yield and quality of maize without nitrogen application. They also determine the optimal dose of nitrogen which was $250 \mathrm{~kg} \mathrm{ha}^{-1}$. Nitrogen deficiency was decreased the grain yield, plant weight and accelerated the senescence. However, there was no significant difference in harvest index (Ding et al., 2005). Grain yield under reduced nitrogen supply was correlated with an increased number of ears per plant, leaf chlorophyll concentration, leaf area index (Kamara et al., 2005). The value of diameter $\times$ plant height was positively correlated maize grain yields, 
and this parameter could be used for refining midseason fertilizer $\mathrm{N}$ rates (Kelly et al., 2015). Recently maize (Zea mays L.) belongs to the most important crops in Hungary and worldwide to. The harvested area was 989 thousand ha in Hungary (KSH, 2018). According to the FAOSTAT (2016) data, the harvested area of maize was 188 million ha worldwide in 2016 and the average yield was $5.6 \mathrm{tha}$ 1 . From the 1960s the yield of maize has increased significantly in the last 50 years (OWID, 2014).

\section{MATERIALS AND METHODS}

Our experiment was performed in the Experimental Station of Látókép (47³3'11" N $21^{\circ} 26^{\prime} 50^{\prime \prime}$ E) near Debrecen on a calcerous chernozem soil. For the experiment three maize (Zea mays L.) hybrids were chosen with different FAO number (Armagnac (FAO 490), Loupiac (FAO 390), Fornad (FAO 420). At the measuring time plants were in "eighth leaf fully emerged" (V8) stage (Hanway, 1963). The forecrop was winter wheat (Triticum aestivum L.). The used agrotechnology was the following: winter ploughing in 2017, the seedbed was prepared with combination at 10/04/2018 and $17 / 04 / 2018$. The date of sowing was at 27/04/2018. The plot's layout was random, and the repetition was four. Length of the plots was 10 metres and 4 rows per plot were sowed. Three level of nitrogen $(\mathrm{N})$ were applied in during the research: $0 \mathrm{~kg} \mathrm{ha}^{-1} ; 80 \mathrm{~kg} \mathrm{ha}^{-1}$; $160 \mathrm{~kg} \mathrm{ha}^{-1}$. The dose of phosphorus (P) and potassium $(\mathrm{K})$ were the same at every plot $\left(60 \mathrm{~kg} \mathrm{ha}^{-1}\right.$ $\mathrm{P}_{2} \mathrm{O}_{5}$ and $90 \mathrm{~kg} \mathrm{ha}^{-1} \mathrm{~K}_{2} \mathrm{O}$ ). Thirty percent of the applied $\mathrm{N}$ dose was spread at the autumn and seventy percent at spring. The last fully developed leaf samples were measured in every plot. The photosynthetic pigment was extracted according to Moran and Porath (1980). The data obtained after the spectrophotometrically determination was mathematically processed based on the equation of Wellburn (1994). For the investigation of relative chlorophyll content two devices were used: SPAD502 (Minolta, Japan) and a handheld GreenSeeker (Trimble, USA). For the statistical analysis SigmaPlot 12.0 for Windows was used (Two-way ANOVA).

\section{RESULTS AND DISCUSSION}

Earlier studies proved the quantitative examination of photosynthetic pigments is suitable in the plant stress researches (Marcu et al., 2013; Saha et al., 2010; Yüzbaşioğlu et al., 2017). The results of the chlorophyll $\mathrm{a}$ and $\mathrm{b}$ content presented on Figure 1.

Figure 1: Changes of the A: Chlorophyll a content $\left(\mathrm{mg} \mathrm{g}^{-1}\right)$ B: Chlorophyll b content ( $\left.\mathrm{mg} \mathrm{g}^{-1}\right)$ of maize hybrids (Armagnac, Loupiac, Fornad) and means of treatments under different $N$ supply $\left(0 \mathrm{~kg} \mathrm{ha}^{-1} ; 80 \mathrm{~kg} \mathrm{ha}^{-1} ; 160 \mathrm{~kg} \mathrm{ha}^{-1}\right) \mathrm{n}=4$, \pm s.e. (differences between means of $\mathrm{N}$ treatments were significant $(\mathrm{p}<0.05)$ in chlorophyll a: $\mathrm{A}: 0 \mathrm{~kg} \mathrm{ha}^{-1}$; $\mathrm{A}: 80 \mathrm{~kg} \mathrm{ha}^{-1}$; $\mathrm{B}: 160 \mathrm{~kg} \mathrm{ha}^{-1}$ and differences between means of $\mathrm{N}$ treatments were significant $(\mathrm{p}<0.05)$ in chlorophyll b: $\mathrm{A}: 0 \mathrm{~kg} \mathrm{ha}^{-1}$; $\mathrm{AB:} 80 \mathrm{~kg} \mathrm{ha}^{-1}$; $\left.\mathrm{B}: 160 \mathrm{~kg} \mathrm{ha}^{-1}\right)$

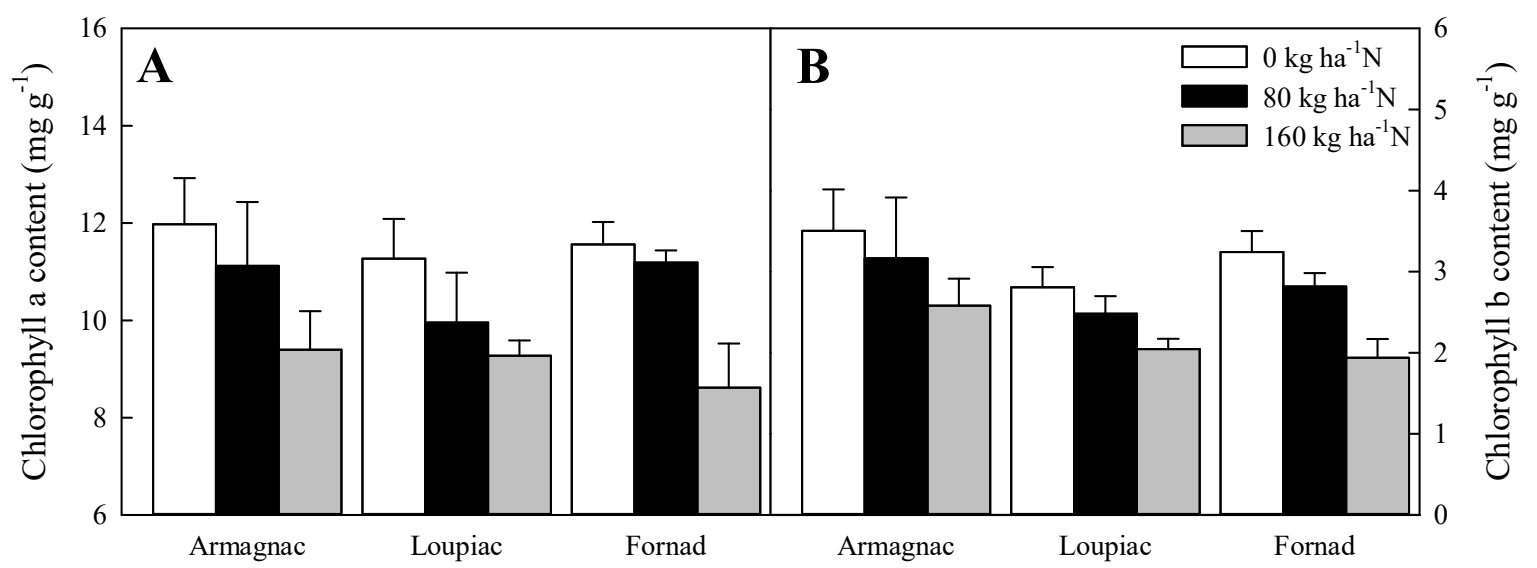

The highest chlorophyll a content $(11.98 \pm 0.95)$ was observed in Armagnac at the lowest level of N. We observed the lowest chlorophyll a content in the case of third hybrid $(9.28 \pm 0.31)$ at the $160 \mathrm{~kg} \mathrm{ha}^{-1}$ level of $\mathrm{N}$. The difference of the chlorophyll a content was the highest between the $160 \mathrm{~kg} \mathrm{ha}^{-1}$ and the 0 $\mathrm{kg} \mathrm{ha}^{-1}$ treatments. In case of Armagnac this difference was $21 \%, 18 \%$ in the case of Loupiac and $26 \%$ in Fornad. These differences were not statistically significant. The tendency of the chlorophyll $b$ content was similar to the chlorophyll a content but the concentration was lower than chlorophyll a. The highest chlorophyll b content $(3.5 \pm 0.51)$ was observed in Armagnac at the $0 \mathrm{~kg} \mathrm{ha}^{-1}$ level of $\mathrm{N}$. We observed the lowest chlorophyll $\mathrm{b}$ content in the case of Fornad $(1.94 \pm 0.23)$ at the $160 \mathrm{~kg} \mathrm{ha}^{-1}$ level of $\mathrm{N}$. The difference of the chlorophyll $\mathrm{b}$ content was the highest between the $160 \mathrm{~kg} \mathrm{ha}^{-1}$ and the $0 \mathrm{~kg} \mathrm{ha}^{-1}$ treatments. In case of Armagnac this difference was $26 \%, 29 \%$ in the case of Loupiac and $41 \%$ in the Fornad. These differences were not statistically significant, but there is a statistically significant difference among the mean values of the different application of fertilizer in the case of chlorophyll $a$ and $b$. In the past a few 
researchers examined the correlation between chlorophyll meter readings and extractable chlorophyll content with different test plants. Kantety et al. (1996) used fescue (Festuca arundinacea) as a test plant and concluded the chlorophyll meter is an easy and efficient method of detecting $\mathrm{N}$ status. Finnan et al. (1997) have made similar conclusions. Reeves et al. (1993) based on their research claimed the chlorophyll meter readings have potential to determine the crops nitrogen status but implemented with other measurements like soil analysis or measuring of the dry matter. Figure 2 contains our results of total chlorophyll content.
These results are similar to that of the chlorophyll b content. The highest chlorophyll content $(15.48 \pm 1.46)$ was observed in the Armagnac at the 0 $\mathrm{kg} \mathrm{ha}^{-1}$ level of $\mathrm{N}$. We observed the lowest chlorophyll content in the case of Fornad $(10.56 \pm 1.1)$ at the 160 $\mathrm{kg} \mathrm{ha}^{-1}$ level of $\mathrm{N}$. The difference of the mean of chlorophyll content was the highest between the 160 $\mathrm{kg} \mathrm{ha}^{-1}$ and the $0 \mathrm{~kg} \mathrm{ha}^{-1}$ treatments. In case of Armagnac this difference was $23 \%, 20 \%$ in the case of Loupiac and $29 \%$ in the Fornad. These differences were not statistically significant, nevertheless similarly to the chlorophyll $\mathrm{a}$ and $\mathrm{b}$ results there is a statistically significant difference among the mean values of the different application of fertilizer.

Figure 2: Changes of the Total chlorophyll content $\left(\mathrm{mg} \mathrm{g}^{-1}\right)$ of maize hybrids (Armagnac, Loupiac, Fornad) and means of treatments under different $\mathrm{N}$ supply $\left(0 \mathrm{~kg} \mathrm{ha}^{-1} ; 80 \mathrm{~kg} \mathrm{ha}^{-1} ; 160 \mathrm{~kg} \mathrm{ha}^{-1}\right) \mathrm{n}=4$, \pm s.e. (differences between means of $\mathrm{N}$ treatments were significant (p<0.05): A: $0 \mathrm{~kg} \mathrm{ha}^{-1}$; A: $80 \mathrm{~kg} \mathrm{ha}^{-1}$; B: $160 \mathrm{~kg} \mathrm{ha}^{-1}$ )

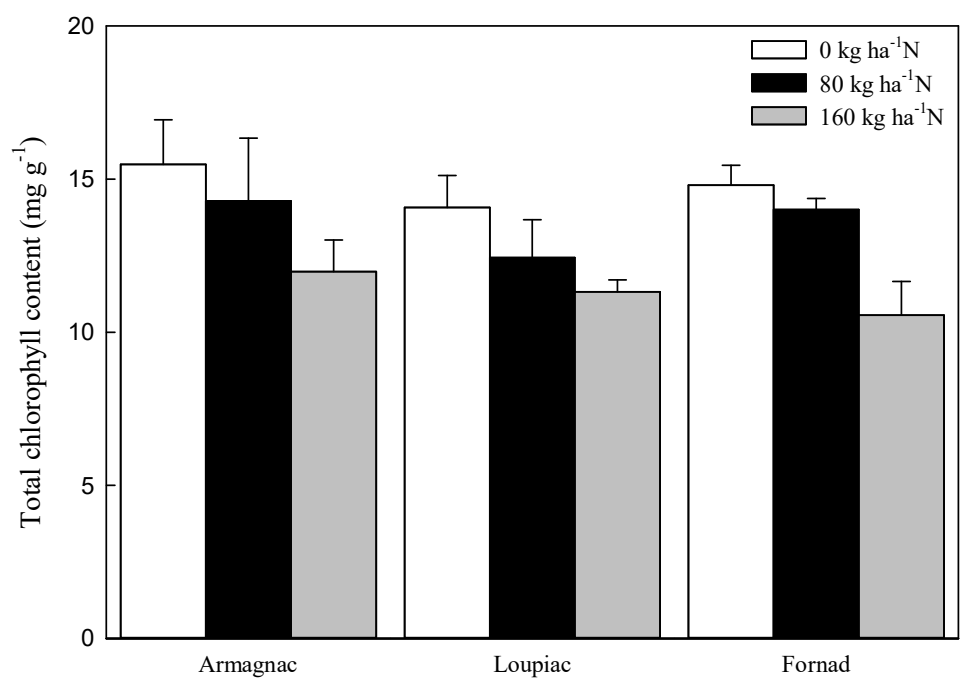

The portable chlorophyll SPAD-502 can be used to analyse the photosynthetic pigments and total $\mathrm{N}$ (Netto et al., 2005). According to Schepers et al. (1992) the SPAD values obtained from SPAD-502 device are correlated with crop nitrogen status. But this can't be practical because of the differences between the genotypes of maize. Bullock and Anderson et al. (1998) claimed the SPAD-502 device can be useful as diagnostic tool to determine the nitrogen status rather than crop management. Our results of SPAD values are presented on Figure 3. The highest SPAD reading $(34.7 \pm 2.97)$ was observed in the Armagnac at the $80 \mathrm{~kg} \mathrm{ha}^{-1}$ level of $\mathrm{N}$. We observed the lowest SPAD values in the case of Loupiac (22.0 \pm 1.76$)$ at the $160 \mathrm{~kg} \mathrm{ha}^{-1}$ level of $\mathrm{N}$. The difference of the SPAD values means was the highest between the $160 \mathrm{~kg} \mathrm{ha}^{-1}$ and the $0 \mathrm{~kg} \mathrm{ha}^{-1}$ treatments in case of Loupiac (24\%). In case of Armagnac this difference was $23 \%$, but this time among the 80 $\mathrm{kg} \mathrm{ha}^{-1}$ and $160 \mathrm{~kg} \mathrm{ha}^{-1}$ dose of $\mathrm{N}$. This difference was $22 \%$ in the Fornad but between the lowest and highest level of applied $\mathrm{N}$ dose. These differences were not statistically significant, but similarly to the chlorophyll results there is a statistically significant difference among the mean values of the different application of fertilizer.

Tingting et al. (2015) prove that the NDVI value may be useful to determine the in-season nitrogen status in maize. The NDVI (Ma et al., 1996) provides in-season indications of $\mathrm{N}$ deficiency. The highest NDVI $(0.47 \pm 0.15)$ was observed in the Fornad at the $160 \mathrm{~kg} \mathrm{ha}^{-1}$ level of $\mathrm{N}$ (Figure 4). We observed the lowest NDVI values in the case of Armagnac $(0.35 \pm 0.007)$ at the $0 \mathrm{~kg} \mathrm{ha}{ }^{-1}$ level of $\mathrm{N}$. The difference of the NDVI was the highest between the $80 \mathrm{~kg} \mathrm{ha}^{-1}$ and the $0 \mathrm{~kg} \mathrm{ha}^{-1}$ treatments in case of Armagnac (8\%). In case of Loupiac this difference was $3 \%$, but this time among the $160 \mathrm{~kg} \mathrm{ha}^{-1}$ and 80 $\mathrm{kg} \mathrm{ha}^{-1}$ dose of $\mathrm{N}$. There was not in the case of Fornad. These differences between the applied $\mathrm{N}$ levels were not statistically significant, but we have evinced statistically significant between the genotypes in this parameter. According to the statistical analysis the three examined genotype can be classified into different groups. 
Figure 3: Changes of the SPAD value of maize hybrids (Armagnac, Loupiac, Fornad) and means of treatments under different $N$ supply (0 kg ha $\left.{ }^{-1} ; 80 \mathrm{~kg} \mathrm{ha}^{-1} ; 160 \mathrm{~kg} \mathrm{ha}^{-1}\right) \mathrm{n}=4, \pm$ s.e. (differences between means of $\mathrm{N}$ treatments were significant (p<0.05): AB: $0 \mathrm{~kg}$ $\mathrm{ha}^{-1}$; A: $80 \mathrm{~kg} \mathrm{ha}^{-1}$; B: $\left.160 \mathrm{~kg} \mathrm{ha}^{-1}\right)$

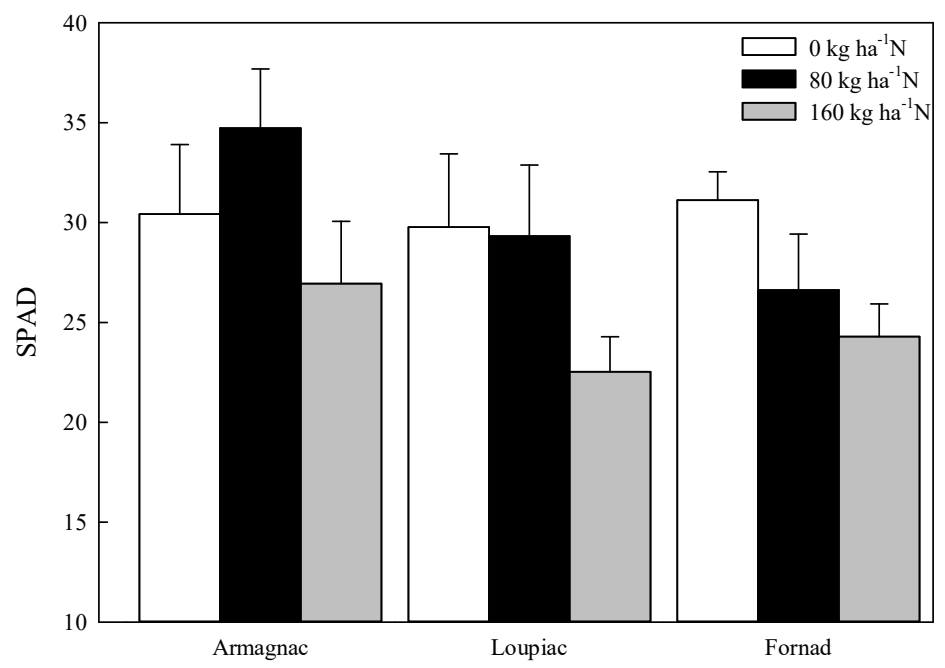

Figure 4: Changes of the NDVI of maize hybrids (Armagnac, Loupiac, Fornad) and means of treatments under different $\mathbf{N}$ supply (0 $\left.\mathrm{kg} \mathrm{ha}^{-1} ; 80 \mathrm{~kg} \mathrm{ha}^{-1} ; 160 \mathrm{~kg} \mathrm{ha}^{-1}\right) \mathrm{n}=4, \pm$ s.e. (differences between treatments and genotypes $(\mathrm{p}<0.05)$ signed with different letters)

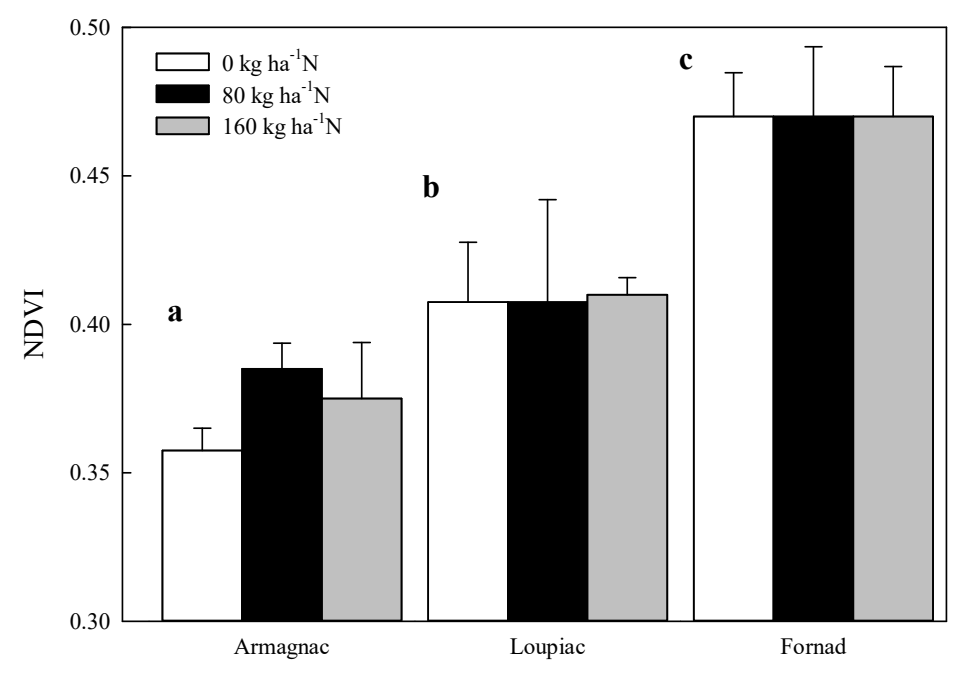

\section{CONCLUSION}

Summarizing the obtained results, most of the measured parameters were not affected significantly by $\mathrm{N}$ deficiency in this early growth stage of corn under field conditions. We need to take into consideration the other important factor which was the effect of pre-crop and the soil type. The crop rotation influenced significantly the yield of maize (Berzsenyi et al., 2000; Fischer et al., 2002). In this experiment the soil type and the forecrop was optimal for maize. The winter wheat in the experimental field at low level $\mathrm{N}$ conditions caused lower level of N-loss at the previous year. Probably these factors reduced the effects of nitrogen deficiency at V8 stage of maize.
Argenta et al. (2004) proved that the SPAD value is more susceptible to errors during maize early growth stages but reliable at the older stages. Although, Freeman et al. (2007) proved that the NDVI value can be use efficient before the V10 growth stages. According to our results the NDVI could not be influenced by the $\mathrm{N}$ dose but we observed differences among genotypes. Armagnac reached the lowest NDVI for the time of examination and the highest values was observed on Fornad. The SPAD values tendencies were more closely to the total chlorophyll, chlorophyll a, chlorophyll b contents. We can conclude the content of all chlorophyll molecules was decreased at the plots where higher $\mathrm{N}$ level was applicated. In contrast nitrogen application improved 
all the chlorophyll pigments, water-related attributes, and yield components (Akram, 2014). Further examination needed to clarify the exact reason of this effect. The measuring of these parameters can be reliable only with other measurements, for example dry weight, Specific Leaf Area or complex soil analysis. Complemented with this kind of measurements these parameters can be suitable for the prediction of in season nitrogen status of crops.

\section{ACKNOWLEDGEMENTS}

The work/publication supported by the EFOP-3.6.3VEKOP-16- 2017-00008 project, and supported by the ÚNKP-18-3 New National Excellence Program of the Ministry of Human Capacities.

\section{REFERENCES}

Akram, M. (2014): Effects of nitrogen application on chlorophyll content, water relations, and yield of maize hybrids under saline conditions. Communications in Soil Science and Plant Analysis. 45.10: 1336-1356.

Argenta, G.-Silva, P. R. F.-Sangoi, L. (2004): Leaf relative chlorophyll content as an indicator parameter to predict nitrogen fertilization in maize. Cience Rural [online]. 34.5: 1379-1387.

Berzsenyi, Z.-Györffy, B.-Lap, D. (2000): Effect of crop rotation and fertilisation on maize and wheat yields and yield stability in a long-term experiment. European Journal of Agronomy. 13.23: $225-244$.

Bullock, D. G.-Anderson, D. S. (1998): Evaluation of the Minolta SPAD-502 chlorophyll meter for nitrogen management in corn. Journal of Plant Nutrition. 21.4: 741-755.

Chapman, S. C.-Barreto H. J. (1997): Using a chlorophyll meter to estimate specific leaf nitrogen of tropical maize during vegetative growth. Agronomy Journal. 89.4: 557-562.

Costa, C.-Dwyer, L. M.-Dutilleul, P.-Stewart, D. W.-Ma, B. L.Smith, D. L. (2001): Inter-relationships of applied nitrogen, $\mathrm{SPAD}$, and yield of leafy and non-leafy maize genotypes. Journal of Plant Nutrition. 24:8: 1173-1194.

Ding, L.-Wang, K. J.-Jiang, G. M.-Biswas, D. K.-Xu, H.-Li, L. F.-Li, Y. H. (2005): Effects of nitrogen deficiency on photosynthetic traits of maize hybrids released in different years. Annals of Botany. 96.5: 925-930.

FAOSTAT (2016): http://www.fao.org/faostat/en/\#data/QC

Finnan, J.-Burke, J.-Jones, M. (1997): A Note on a non-destructive method of chlorophyll determination in wheat (Triticum aestivum L.). Irish Journal of Agricultural and Food Research. 36.1: 85-89.

Fischer, R. A.-Santiveri, F.-Vidal, I. R. (2002): Crop rotation, tillage and crop residue management for wheat and maize in the sub-humid tropical highlands: II. Maize and system performance. Field Crops Research. 79.2-3: 123-137.

Freeman, K. W.-Girma, K.-Arnall, D. B.-Mullen, R. W.-Martin, K. L.-Teal, R. K.-Raun, W. R. (2007): By-Plant prediction of corn forage biomass and nitrogen uptake at various growth stages using remote sensing and plant height. Agronomy Journal. 99: 530-536.

Garousi, F.-Veres, S.-Kovács, B. (2015): Non-destructive and destructive measurements' chlorophyll content in sunflower and maize plants uptaken different chemical forms of selenium. Columella - Journal of Agricultural and Environmental 2.2: 915.

Hafez, E. M.-Abdelaal. K. A. A. (2015): Impact of nitrogen fertilization levels on morphophysiological characters and yield quality of some maize hybrids (Zea mays L.) Egyptian Journal of Agronomy. 37.1: 35-48.
Hammad, H. M.-Ahmad, A.-Khaliq, T.-Farhad, W.-Mubeen, M. (2011): Optimizing rate of nitrogen application for higher yield and quality in maize under semiarid environment. Crop \& Environment. 2.1: 38-41.

Hanway, J. J. (1963): Growth stages of corn. Agronomy Journal. 55. $487-492$.

Jiang, C.-Johkan, M.-Hohjo. M.-Tsukagoshi, S.-Maruo. T. (2017): A correlation analysis on chlorophyll content and SPAD value in tomato leaves. HortResearch 71: 37-42.

Kalaji, H. M.-Oukarroum, A.-Alexandrov, V.-Kouzmanova, M.Brestic, M.-Zivcak, M.-Samborska, I. A.-Cetner, M. D.Allakhverdiev, S. I.-Goltsev, V. (2014): Identification of nutrient deficiency in maize and tomato plants by in vivo chlorophyll a fluorescence measurements. Plant Physiology and Biochemistry. 81: 16-25.

Kamara, A.-Menkir, A.-Ajala, S.-Kureh, I. (2005): Performance of diverse maize genotypes under nitrogen deficiency in the northern guinea savanna of Nigeria. Experimental Agriculture. 41.2: 199-212.

Kantety, R. V-Santen, E.-Woods, F. M.-Wood, C. W. (1996): Chlorophyll meter predicts nitrogen status of tall fescue. Journal of Plant Nutrition. 19.6: 881-889.

Kelly, J.-Crain, J. L.-Raun, W. R. (2015): By-plant prediction of corn (Zea mays 1.) grain yield using height and stalk diameter. Communications in Soil Science and Plant Analysis. 46.5: 564575.

KSH (2018): http://www.ksh.hu/docs/hun/xstadat/xstadat_eves/i_ omn001b.html

Lu, Y.-Hao, Z.-Xie, C.-Crossa, J.-Araus, J. L.-Gao, S.-Vivek, B. S.-Magorokosho, C.-Mugo, S.-Makumbi, D.-Taba, S.-Pan, G.-Li, X.-Rong. T.-Zhang, S.-Xu, Y. (2011): Large-scale screening for maize drought resistance using multiple selection criteria evaluated under water-stressed and well-watered environments. Field Crops Research. 124.1: 37-45.

Ma, B. L.-Morrison, M. J.-Dwyer, L. M. (1996): Canopy light reflectance and field greenness to assess nitrogen fertilization and yield of maize. Agronomy Journal. 88: 915-920.

Marcu, D.-Damian, G.-Cosma, C.-Cristea, V. (2013): Gamma radiation effects on seed germination, growth and pigment content, and ESR study of induced free radicals in maize (Zea mays). Journal of Biological Physics. 39.4: 625-634.

Moran, J. A.--Mitchell, A. K.-Goodmanson, G.-Stockburger, K. A. (2000): Differentiation among effects of nitrogen fertilization treatments on conifer seedlings by foliar reflectance: a comparison of methods. Tree Physiology. 20: 1113-1120.

Moran, R.-Porath, D. (1980): Chlorophyll determination in intact tissues using N,N-dimethylformamide. Plant Physiology. 65.3: 478-479. 
Nagy, J. (2010) Impact of fertilization and irrigation on the correlation between the soil plant analysis development value and yield of maize. Communications in Soil Science and Plant Analysis. 41.11: 1293-1305.

Netto, A. T.-Campostrini, E.-Oliveira, J. G.-Bressan-Smith, R. E. (2005): Photosynthetic pigments, nitrogen, chlorophyll a fluorescence and SPAD-502 readings in coffee leaves. Scientia Horticulturae. 104.2: 199-209.

OWID: https://ourworldindata.org/grapher/global-map-of-maizeyields

Peñuelas, J.-Filella, I. (1998): Visible and near-infrared reflectance techniques for diagnosing plant physiological status. Trends in Plant Science. 3: 151-156.

Pepó, P. (2010): Adaptive capacity of wheat (Triticum aestivum L.) and maize (Zea mays L.) crop models to ecological conditions. Növénytermelés. 59: 325-328.

Purcărea, C.-Cachiță-Cosma, D. (2010): Studies regarding the effects of salicylic acid on maize (Zea mays L.) seedling under salt stress. Vasile Goldis University Press. 20.1: 63-68.

Reeves, D. W.-Mask, P. L.-Wood, C. W.-Delaney, D. P. (1993) Determination of wheat nitrogen status with a hand-held chlorophyll meter: Influence of management practices. Journal of Plant Nutrition. 16.5: 781-796.

Richardson, A. D.-Duigan, S. P.-Berlyn, G. P. (2002): An evaluation of noninvasive methods to estimate foliar chlorophyll content. New Phytologist. 153: 185-194.

Saha, P.-Raychaudhuri, S. S.-Chakraborty, A.-Sudarshan, M. (2010): PIXE analysis of trace elements in relation to chlorophyll concentration in Plantago ovata Forsk. Applied Radiation and Isotopes. 68: 444-449.

Schepers, J. S.-Francis, D. D.-Vigil, M.-Below, F. E. (1992): Comparison of corn leaf nitrogen concentration and chlorophyll meter readings. Communications in Soil Science and Plant Analysis. 23.17-20: 2173-2187.
Schlemmer, M.-Gitelson, A.-Schepers, J.-Ferguson, R.-Peng, Y.Shanahan, J.-Rundquist, D. (2013): Remote estimation of nitrogen and chlorophyll contents in maize at leaf and canopy levels. International Journal of Applied Earth Observation and Geoinformation. 25: 47-54.

Simkó, A.-Bodnár, K. B.-Veres, S. (2018): A SPAD és NDVI értékek alkalmazhatóságának vizsgálata a klorofill koncentráció függvényében kukoricánál. Növénytermelés. 67.2: 45-56.

Széles, A. (2007): The indication of nitrogen deficiency in maize growing using SPAD502 chlorophyll meter. Cereal Research Communications. 35.2: 1149-1152.

Tingting, X.-Yuxin, M.-Guohua, M.-Khosla, R.-Dali, W.-Hui, S.Xinxing, X. (2015): In-season estimation of spring maize nitrogen status with GreenSeeker active canopy sensor. 2015 Fourth International Conference on Agro-Geoinformatics (Agro-geoinformatics). 390-395.

Verhulst, N.-Govaerts, B.-Nelissen, V.--Sayre, K. D.-Crossa, J.Raes, D.-Deckers, J. (2011): The effect of tillage, crop rotation and residue management on maize and wheat growth and development evaluated with an optical sensor. Field Crops Research. 120.1: 58-67.

Wellburn, A. R. (1994): The spectral determination of chlorophylls $a$ and $b$, as well as total carotenoids, using various solvents with spectrophotometers of different resolution. Journal of Plant Physiology. 144: 307-313.

Yüzbaşioğlu, E.-Dalyan, E.-Akpinar, I. (2017): Changes in photosynthetic pigments, anthocyanin content and antioxidant enzyme activities of maize (Zea mays L.) seedlings under high temperature stress conditions. Trakya University Journal of Natural Sciences. 18. 2: 1-8. 